ber det, udstoder hun et sprudlende watahke og ser pásin mor. Moderen ser tilbage pa hende og trakker pa skuldrene og udforer en slags rystedans med overkroppen ligesom en gomgo danser. Dansen varer kun nogenlunde lige så lenge som datterens waahha, men er lige så optrendt, glad og intens.

6 Stem fravalger (efter megen diskussion) brugen af begrebet "imitation' on den afstemmende adferd for at understrege den indre follelsesmassige dimension ved adfarden. Imitation gengiver form; afstemning gengiver folelse siger han (Stern 1991: 151) - ikke for at opstille en absolut dikotomi, men for at betone, at de placerer sig i hver sin ende af et spektrum.

7 Stern redegor ikke namere for, horfor han betegner foleserne ved hyelp af termen vitalitet, udover referencen till Susanne Langer om de vitale livsprocessers folelsesmassige betydning som en slags indre dynamo, der hjolper med til at adskille kategorien levende fra kategorien ikke-levende. Men den vitale impuls ma for mig at se ogsä tilskrives den specifikke sansemassige stimulation, som den affetive afstemning baserer sig pa, hvor, som Stern bekrafter gennem sine undersogelser, bamet or i besiddelse af cn medfodt evne til amodal perception, dvs. vil aplatte information inden for en given sensorisk modalitet og overfore den til en anden sensorisk modalitet (Stern 1991; 57f.) - en evne og aktivitet, som givetvis foles og opleves som vaerende af vital karakter.

8 Her mă gores opmarksom på, at en vacsentlig kritik af Stern angär hans manglende refleksion af beydningen af en kulturel kontekst i sin teori om barnets udvikling. Se bla. Sommer (1996: 170-180).

9 Wilalitets folelser forekommer badde, năr kategoriale folelser er til stede og ikke er til stede. Feks. kan et vredesmbrus eller en gladesmbolgee, et oplevet vald af lys og lethed, en stormende tankerake, umadelige og store folelser fremkaldt af musik aller et skud narkotika alt sammen opleves som »brusk. De har alle ensartet neural fyringsaktivitet om end i forskellige dele af nervesystemet. Den oplevede kwalitet ved hver enkelt af disse nogenlunde ensartede forandringer er de, jeg kalder \$brusets witalitetsfolelse (Stem 1991: 65).

10 Stem argumenterer for at adskille vitalitetsfolelser fra kategoriale folelser med henvisning til, at de forstnavrte ikke kan forklares ud fra begrebet aktiveringsniveau. mI de fleste redegorelser for folelser og deres dimensioner vil det, vi her kalder vitalitetsfolelse, vare rubriceret under aktiveringsmiveaucts $\mathrm{d}-$ ler spandingsgradens (arousalmiveauets) altomfattende og skiftende dimension. Aktivering og spending kommer sả sandelig frem, men de opleves ikke blot og bart som folelser ud af eller et eller andet sted pa denne dimension. De opleves som dynamiske wndringer, forandringer der folger et vist monster inde $i$ os selv. Vi kan kun bruge dimensionen spanding-aktivering som en generel indikator for spandings- og aktiveringsgraden. Men vi bliver nodt til at foje en fuldstrendig ny inddeling til for at fa vitalltetsfolelsernes warving af oplevelsen med, der svarer til andringer, som kan have karakteristiske monstre. Disse monstrede w wandringer over tid, $\mathrm{cl}$ ler altivitets-omrids, ligger bag de enklete vitalitetsfolelser (Stern 1991: 66-67).

11 Stern giver et illustrativt eksempel herpa ved at referere til en fotograf, sombad en kvinde om at trenke pä forskellige emner. Emnerne var: hendes mor, hendes far, hendes bror, hendes tidligere selv, hendes nuvarende selv og hendes fremtidige selv. Fotogram fen tog et billede af kvindens ansigt for hvert emne tilstand. Kvinden fremviste ikke nogen genkendelig eller navngiven kategoriel folelse, idet hendes ansigt stort set var neutralt pa samtlige fotograber, wen de wstlistiske forskelle var markante. Hvert fotom grafi var en indfanget vitalitetsfolelse«, skriver Stern (1991: 302).

12 Det er specielt i forhold til unges muntre kommentarer til de voldsomme secner i Pulp Fiction, at Annc Jerslev (1999) anvender kanakteristikken klassisk synisme. Som i mit materiale forbinder de unge en fundamental kropslig tilfredshed med at vare tilskuere til den totalt fanden-íwoldske omvendelse af alle verdihierankier.

\section{Litteratur}

Garroll, Noel (1997) m Art, Narrative, and Emotionk, pp. 190-21l in Mette Hjort og Sue Laver (red.) Emotion and the Arts New York: Oxford University Press.

Christensen, Christa Lykge (1999) "Forstälse og tolkm ning af moderne billedmedier: om danske gymnasieclevers billedoplevelser «, pp. 243-26l in Burt, unge og medier. Goteborg: Nordicom.

Culler, Jonathan (1975) Structuralist Poetics. Structuralism, Lingustics and the Study of Literature London: Routledge.

Funch, Bjarne Sode (1997) "Billed-kunst i psykologisk belysuing 2 , Pyke \&ogos 18, 1:132 47.

Hansen, Mogens (1997) Intullgens og tenkming: en bog om kognitiv psyologi Padagogisk Serie nr. 18. Horsens: Forlaget lokke.

Iser, Wolfgang (1978) The Act of Reading AThory of Aesthtic Response Baltimore: John Hopkins University Press. Opr. 1976 .

Kock, Christian (1994) "Hvad laser vi for? Er litteraturens interessemoment semantisk eller psykodynamisk? \& Edda 4: $319-335$.

Rosenblat, Louise (1978) The Reader the Text, the Poem: The Tramsactional Theory of the Literary Work Carbondale: Southern Illinois University Press.

Roscnblatt, Louise (1995) Literature as Explaration New 1onk: Modem Language Association of America. Opr. 1938.

Sommer, Dion (1996) Bandomspsyhologi. udwhling ien forandret verden Kobenhavn: Hans Reizes Forlag.

Stern, Danid N. (1991) Banets inteversonelle univers Kom benhavn: Hans Reizels Forlag. Opr. 1985. 


\title{
Tilbage til virkeligheden: en undersøgelse af danske unges reklamesmag
}

\author{
JohnThorup
}

\begin{abstract}
Siden slutningen af 1980'rne har ungdomsreklamen veret praget af en brudestetik-ungdomsreklamer har udfordret dominerende moralforestillinger, klassiske kropsidealer og konventielle fortelleformer. Det antages ofte i reklamebranchen og $i$ ungdomsforskningen, at disse reklamer er udtryk for en tidstypisk ungdommelig smag. Men kan de unge overhovedet lide brudreklamerne? Forfatteren har interviewet 20 unge kobenhavnere om deres reklamesmag, og analyserne peger pä, at informanter ne foretrakker reklamer, hoor fortalling og restetik er mere traditionel end i brudreklamen, dos. danske reklamer der forteller historier om det senmodernes kompleksitet. Ifolge forfatteren indikerer resultatet, at vi må forstå forholdet mellem unge og reklame anderledes, end vi gor idag.
\end{abstract}

Bom og unge kan lide reklaner der er flot lavet, har en historie, humor og en god lydside (Tufte 1994: 105).

Man skal lede længe, hvis man vil finde et udsagn om unges reklamesmag, der er mindre sensationelt end ovenstående. Ikke alene er det noget nar indlysende, at unge synes, en reklame skal vare flot og have en god lyd, men det er også lidt kedeligt, at unge skulle have en smag, der cr så ordinar. Alligevel vil jeg havde, at Birgitte Tufte rammer tattere på unges reklamesmag end samtlige andre af tidens ungdoms- og reklameforskere.

\section{Brudreklamer}

De seneste ti år har ungdomsreklamen varet praget af en sæerlig anti- eller brudæstetik. Man har set provokerende reklamer for bla RemRem, Jigsaw og Nike, der bevidst udfordrer dominerende moralforestillinger med billeder af død og ulykke. Man har set reklamer for bla. Calvin Klein og Diesel, der udtrykker en stigende ambivalens overfor det klassiske modne « kropsideal om harmoni, kontrol, sundhed og kon, og man har set reklamer for bl.a. Sprite og Jolly Cola, der parodierer de klassiske, finale fortalleformer. ${ }^{1}$

En af årsagerne, til at vi ser dette skift, er, at re- klamen i stigende grad kommunikerer til trendsetterc, dvs en gruppe af unge kendetegnet ved en stark orientering mod fornyelse og forandring mod brud. Samtidig er der sket et generelt skift i reklamebranchens opfattelse af deres unge malgrupper, et skift inspireret af et tilsvarende skift i ungdomskulturforskningen.

For det forste opfatter man i dag unges identitet primart som et socialt fanomen. Unge orienterer sig positionelt og konstruerer en sammenhangende identitet primart ved at distancere sig fra den etablerede kultur og forældrekulturen. Dette ungdomssyn er en konsekvens af det skift, der er sket i kulturforskningen fra det psykologiske paradigme, der dominerede i 1970 'erne og i starten af 1980 'erne til det sociologiske paradigme, der dominerer i dag. Her er Thomas Ziches vark eksemplam risk. Irolge Ziehe er unges forhold til verden og reklamer således ikke langere primart styret af deres behov og skjulte driftsonsker, men af deres smag og kompetencer. Tilsvarende er unge i denne optik ikke lengere sărbare og modtagelige men aktive, kompetente, innovative, kulturkritiske, mediekritiske og - vigtigst - meget moderne Uerslev 1993, Drotner 1995).

For det andet er man meget fokuseret på det forhold, at unge er serligt optaget af kroppen og dens 
iscenesæettelse (Stormhoj 1994), og for det tredje hersker en forestilling om, at unge er meget optaget af mediernes udtryk stil, astetik og intertekstuelle referencer (Nava 1990, Jerslev 1993: 139ff, Odonahue 1997).

Reklamebranchen forestiller sig, at disse kendetegn ved 90 'ernes unge skulle komme til udtryk i en praference for de ovennavnte sbrudreklamer hos de unge. Problemet er blot, at der ikke er megen forskning i unges reklamereception, der bekrefter dette.

\section{Hvad er en god reklame?}

I efteråret 1997 gennemforte jeg en empirisk undersøgelse af en gruppe danske unges reklamesmag. Undersogelsens formål var at blive klogere pă to sporgsmål: hyad synes de unge er en god reklame? Og hvad er det, der gor den god?

Resultaterne peger på nogle generelle tendenser i 90'er-ungdommens smag og behov og rejser en rakke sporgsmål til nogle af de pkanoniske forestillinger om unges oplevelse af reklamer. Mine informanter orienterer sig nemlig mod en helt anden type reklamer end de ovennavnte brudreklamer. Deres reception kredser ikke om social identitet, men snarere om personlig autenticitet; den kredser ikke om kropsrepresentationer, men snarere om windre kvaliteter, og den er ikke stilorienteret, men snarere indlevet og handlingsorienteret..

Undersøgelsens resultater peger således i samme retning som Birgitte Tuftes undersogelser. Birgitte Tufte udpeger fire af de unges krav til en reklame. Men det er faktisk muligt at udvide listen over unges astetiske krav og dermed nuancere og pracisere beskrivelsen af danske unges reklamesmag. Det vil jeg gore i det folgende, samtidig med at jeg sætter de unges reklameoplevelser ind i en kulturteoretisk sammenhang og diskuterer de problemer, det rejser for reklamebranchen, at de unge stort set overser de deciderede ungdomsreklamer, dvs. reklamer for varer rettet mod unge.

Artiklen bygger på en rakke kvalitative enkeltinterviews, jeg foretog med 20 københavnske unge i alderen 16-20 âr. Jeg snakkede med ti gymnasicelever fra $3 . \mathrm{g}$ og ti elever fra andet år på teknisk skole med ligelig konsmassig fordeling. For at skabe en tryg ramme og for at reducere situationens indbyggede asymmetri foregik intervicwene hjemme hos de unge. Hensigten var at omdefinere interviewsituationens roller med interviewer over for interviewoffer til en art minteresseret samtale«. Samtidig skulle de hjemlige omgivelser minimere risikoen for, at informanterne opfattede situationen som en larerelev relation (qua min institutionelle forankring på universitetet). Denne risiko blev dog reduceret af, at mange af informanterne pä grund af min unge alder/min usikre fremfard troede, jeg var studerende. Målet var at skabe on stemning af »fortrolighed《. Samtidig skulle de hjemlige omgivelser og ansigt-til-ansigt situationen give mig information om de unges kulturelle 'ståsted' - bagrundsviden der skulle tjene til at nuancere og kvalificere fortolkningen af deres udsagn.

Jeg ville gerne have, at samtalen kom til at bygge $p a ̈$ informanternes egne reklameoplevelser deres cgen smag og crindring. Derfor indledte jeg interviewene med at sporge de unge om folgende: hvad er den seneste reklame, du har set? Er der nogen reklamer, du kan lide/ikke kan lide? Er der nogen reklamer, du af en eller anden grund kan huske?

Dybdeinterviewet giver mulighed for at fortolke - men det sikrer også, at man undgår at fortolke for meget: her har man nemlig, modsat det kvantitative interview (fx telefoninterviewets afkrydsningsskema, der bruges flittigt af markedsanalyseinstitutterne) mulighed for at folge op pa uklarheder, forfølge interessante tankegange og stille uddybende sporgsmål.

\section{Posttraditionelle komedier}

En mand i tyverne sidder på en café og făr sig en ol. Ved bordet overfor sidder en kedelig, snerpet kvinde med sygekassebriller. Manden drikker en tår af sin $ø$ log bliver noget forbavset, da han sxtter glasset fra sig og ser, at kvinden har taget briller og hărspæender af. Manden kigger forundret på sin ol, drikker endnu et glas og kan ikke tro sine egne ajne, for kvinden er nu blevet forvandlet til et lakkert skär. Scenen gentager sig, indtil der sidder en supersexet - og liderlig - amazone over for den torstige unge mand. Han gnider sig begejstret $i$ ajnene og ak, igen sidder den vindtorre gammeljomfru over for ham. Et kort øjeblik er manden rystet, men så genvinder han fatningen og begynder ivrigt at signalere til tjeneren efter nye forsyninger.

Ovennavnte handling udspiller sig i en reklamefilm fra 1993 for Gron Tuborg, og det er en rigtig god reklame ${ }^{2}$ Saledes var det den reklame, der oftest blev fremhxet af mine informanter. Filmen 
er en klassisk fortallende reklame. Den har en protagonist med et klart defineret projekt og en kausalt udfoldet handling. Og det er ct gennemgående trak ved informanternes favoritreklamer. 17-ărige Anton sagde om reklamen:

Så kumne jeg bedre lide den, der var sidste år med øl, hvor han kiggede gennem glasset - det er i fjernsynet - han sidder ved siden af en fed dame, som man får indtryk af er hans kone. Og når han så drikker, begynder hun at smide tøjet og bliver lige pludselig lidt mindre, og lidt mere lakker at se på ... og det vil sige fuck, han skal sgu have mere.

Som det fremgår, husker Anton ikke, hvad det er for et varemarke, der reklameres for, og han husker kun reklamens handling svagt (kvinden er ikke fed, og hun er ikke hans kone). Alligevel husker han, at reklamen var god, og hans begrundelse peger på en af årsagerne til reklamens popularitet:

det er da mere dansk mentalitet ... humor men også en danskhed, jeg kender det med nogle af mine kammerater, der har det på den måde, at efter et par pilsnere, der er det da shej hej, søde lille du «; for et par timer siden ville de have sagt , hende der, has.

Anton oplever reklamen som satire over ellets virkning på brunstige unge mand, og som det fremgår, er det vigtigt, at han kender situationen fra sit eget liv. Det sxrligt danske, han hentyder til, angår sảledes både reklamens tematik (en saerlig kødelig svaghed hos danske drenge) og dens perspektiv (den refleksive humor).

Endnu et eksempel antyder, hvad det er, der er på spil. Tre gymmasieelever syntes, at Vores Ol-reklamen »Kollektivet « var en god og »skideflot « reklame. Ulf Pilgaard spiller en kollektivist, der viser en ny beboer rundt i kollektivet. Han beskriver alt som wvores og implicerer dermed, at man i god kollektivistisk and deler alt med hinanden - selv tandborsten. Rundturen ender ved en seng, hvorpå der står cn kasse Carlsberg, og det far den ny beboer til at konkludere, at så må det jo vaere »vores olk. I samme nu kaster Pilgaard sig beskyttende over kassen og snerrer vredt: "Det er min ol, og du holder snitterne vak k.

Reklamen er en satire over en forældregeneration, der har forrädt de smukke idealer fra hippietiden og ungdomsoproret (den kollektivistiske idé om lighed og fallesskab) men samtidig er det en historie, der tematiserer en konflikt mellem to behov behovet for et socialt tilhorsforhold og behovet for personlig integritet. Dette er en konflikt, der har sarlig relevans for unge, fordi de er i en periode af livet, hvor de pá den ene side er ved at udvikle en selvstændig, »ung《 identitet (der ofte vil bygge pa et vardisæt, der er forskelligt fra forialdrenes voksenidentitet) og pa den anden side skal bruge kammeraterne at stotte sig til i denne proces (Larsen 1999).

Det er et genkommende trak i de unges favoritreklamer, at de appellerer til et selvrefleksivt grin. til at man grincr ad sig selv og sine egne svagheder. Gymnasiepigerne Ina (18 år) og Anna Louise (17 år) kunne eksempelvis begge lide den samme reklame for Tele Danmark. Ina sagde:

Den er suverxen TeleDanmark har den med den unge pige, der fortaller sin far, at hvis nu Per han ringer, så vil jeg gerne tale med ham, og hvis det er Ole, sà er jeg ikke hjemme, og hvis Janni ringer, skal jeg have telefonen lige med det samme - det er meget vigtigt. Să ringer telefonen, og så siger han, Det er Ole«, og så spørger faren ser det ham, du ikke ville tale med - og bliver sa irriteret. Den er god, for den henvender sig til alle unge. Alle har det der, shvis nu deter Bo«, man kender det selv. Den nikker man genkendende til, så den husker man.

Tilsvarende mente Anna Louise, at reklamen var »så komisk og så typisk samtidig. Naturlig, for det er jo seadan det erk.

\section{På sporet af et agte menneske}

Tuborg-, Carlsberg- og Tele Danmarkreklamerne har det til falles, at det er danske reklamer, der på humoristisk vis iscenesatter typiske (hverdags) situationer, hvor personerne pà den ene eller anden made afslorer en svaghed.

De unges favoritter er danske reklamefilm, der tematiserer nogle af det senmoderne livs centrale konflikter. For Ina, Anne Louise og Anton er en »sand « reklame en god reklame. Gode reklamer er reklamer, der kan sige noget centralt om livet pả en sjov măde. Reklameme tematiserer erfaringer eller situationer, de unge kender fra deres eget liv. Samtidig er reklamernes personer autentiske individer, ikke selvsikre superheltc. Det er kornm plekse figurer, hvis indre, msande jeg vi får adgang til. Reklamens hovedpersoner er antihelte, dvs. figurer hvis svagheder vi identificerer os med eller tager afstand fra (jf. Thomp 1997). Vi tilegner os ikke figurernes ideale, »guddommeligek egen- 
skaber som i den klassiske reklame, men deres genm kendelighed eller menneskelighed. Antihelten er en meget anvendt type i danske reklamer og optrader også i de fleste af de unges favoritreklamer. Antihelten er en tryghedsskabende figur, der inviterer til jeg-identifikation. Han rummer ikke den potentielle trussel som reklamens traditionclle wuopnåelige« idealfigurer gør og så virker han autentisk.

Reklamerne skildrer identitet som noget clastisk, skrøbeligt og komplekst, som en storrelse praget af et vald af modstridende behov. De tematiscrer følelser og subjektivitet med historier om $\mathrm{fx}$ venskabsforhold og "gå-i-byen -livet. Det galder Teledanmark-reklamen, der tematiserer ungdomslivets komplicerede net af relationer og viser en pige, der vil leve et selvstandigt ungdomsliv (uden faderen), men samtidig virker barnlig i sit enorme krav om engagement fra faderens side. Det galder oldrikkeren med den svage moral $i$ Gron Tuborgreklamen, og det galder den sociale kollektivist i Vores Ol-reklamen, der pludselig afslorer en egoisme, som ikke svarer til hans idealistiske selvfremstilling.

Informanterne tiltrakkes af disse ambivalente individer og af en humor, der gor det muligt at reflcktcre det moderne (ungdoms) livs kompleksitet.

\section{Autenticitet og enkelhed}

Vi finder også antihelten i en seric danskproducerede reklamefilm for McDonalds, der blev nevnt afflere gymnasicelever, bl.a. Anna-Louise:

En reklame, jeg kunne lide, er den for McDonalds. Den med ham eleven der havde bestilt for mange. Man snakkede om den og behøvede ikke se den mange gange, fordi den var sả enkel.

Anne-Louise havde let ved at tilegne sig reklamen, og hendes ordvalg tyder da også pà en vis identitfikation med medarbejderen fra McDonalds. Hun omtalcr ham som welev《, uden at denne titel novnes i reklamen. Dermed markerer hun et fallesskab med han, hun er også selv (gymnasie) elev. Den desperate medarbejder, der forsoger at redde sig ud af sin knibe, ved at appellere til vores forståelse, inviterer til indlevelse og medlidenhed, og det var da også kun piger der nævnte reklamen. Gymnasiepigen Anja mente, at:

Reklamen var god. Det er en, hvor han står »jeg gor det aldrig mere, du skal købe den«. Man tankte, er det nu også rigtigt, at der er $\mathrm{cn}$, der har bestilt for meget kød hjem. Jeg havde medlidenhed med dem ,.. men jeg gik ikke ind og kobte en burger.

Som det fremgär, var Anja i tvivl om historiens agthed. Dette skyldes reklamens enkle og dokum mentariske fortalleform. 'Medarbejderen' refererer ikke blot til en mulig virkelighed (den forkerte bestilling), han henvender sig også direkte til publikum, og der klippes ikke. Det er disse faktakoder, der skaber reklamens autcnticitet og dens realitetseffekt.

Stilistisk minder McDonalds-reklamen om en af 90'ernes mest succesrige reklamekampagner, nemlig kampagnen for boller fra Kohberg. Her 'kastes' en uforberedt fabriksmedarbejder/'bager' ind foran kameraet. Han smiler panisk og ved ikke, hvad han skal sige. Det resulterer i, at hans salgstale primart består af lange 'pinlige' pauser, afbrudt af spede udbrud a la »de smager jo godt og wder er mange af deme. Thomas H. syntes, at reklamen var fjing fjong, sfordi det bare er sădan noget impulsivt noget, og så de der attituder han render rundt med, nå jah sădan lidt lalleglad $k$.

Reklamen er en metareklame i den forstand, at den fungerer som modbillede til den traditionelle reklames smarte og selvsikre sxlgere. Men reklamens planløse, uindstuderede og umiddelbare prag giver den også et 'virkelighedsprag', en autenticitet, der forstarker den 'hjælpelose', 'Tille' lagermands trovardighed. Samtidig er reklamen jo uhyre enkel, og enkelhed var generelt et kvalitetskriterium. Gymnasiepigen Pernille sagde $\mathrm{fx}$ om reklamen for Gron Tuborg:

Det er mest enkle reklamer, hvor det er en skuespilm ler, der rykker ret meget, der er gode. På et tidspunkt var der en for Tuborg, tror jeg, med en mand, der kigger på en olflaske, nej han kigger på en rovkedelig dame, der sidder og drikker te. Hende far han nogle fantasier om, tager tojet af hende osv. Han var da totalt sej, fordi han spillede så godt. Det er meget bedre end hurtige klip.

Pernille ser enkelheden i direkte modsatning til det, der ofte beskrives som typisk ungdommeligt, nemlig den stilfokuserende MTV-restetik. Rationalet bag Pernilles smagsideal er, at cnkelhed er tegn på, at man har noget på hjerte, er arlig og trovardig. MTV-restetikken blev afvist af de fleste informanter, der som Pernille bedre kunne lide en mere klassisk »sømlas fortellemåde med rolig ka- 
meraforing, rolig klipning, naturtro belysning osv. Nazim fra teknisk skole beskrev M'TV-astetikken som »overdrevne amerikanske reklamer«, og Pernille sagde:

Sådan noget ungdoms-noget på en strand og motion og sådan noget er forfardelig. Det virker, som om nogle gamle mand har siddet på et kontor og nu skal få unge til at synes, det her er hipt, og så prover de virkelig at finde melodien, nu skal vi på stranden og hore høj musik - MTV-beach og sådan noget.

Gymnasiedrengen Rune fortsætter ad samme spor i sin karakteristik af en Stimorol-reklame:

Det virker som et forsog på at appellere overdrevent til ungdommen. Det er langt vak fra det, jeg bryder mig om. Den overfriske ungdomsting, at det skal vxre tjept og friskt og cool.

Reklamer der soger at ramme en sæerlig ungdommelig stil eller fremstille »ungdommelige universer, falder ikke i informanternes smag. Pernilles forestilling om, at reklamerne er lavet af gamle mand, viser, at disse reklamers inautentiske universer og figurer narmest virker krænkende - som umyndiggorende forsog på at definere hvad der er ungt.

\section{Ambivalens til salg}

Som navnt i indledningen er kroppen og dens iscenesattelse et vigtigt omdrejningspunkt for unges identitetsarbejde. "Dels falder konsmodningen sammen med en stigende interesse for toj og mode« (Stormhøj 1994: 141), dels skulle den postmoderne kultur betyde, at identitet i stigende grad bliver et resultat af stil, look og image (Kellner 1995: 259). Alligevel er den forventelige interesse for kropsreprasentationer aldeles fraverende $i$ de unges reklameoplevelser. De unges praferencer er i stedet praget af en orientering mod klassisk fortalte historier og personer med interessante, windre« kvaliteter.

Inspireret af socialkonstruktivismen mener den engelske sociolog Antony Giddens, at vi skaber vores identitet ved at konstrucre en sammenhangende biografisk fortelling. Måle for vores identim tetsarbejde er at skabe sammenhang mellem hold.. ninger og handlinger. Giddens mener, at det kendetegner samtidens kultur, at den er posttraditionel. Traditionerne kan ikke langere levere selvfolgelige og naturlige virkelighedsfortolkninger.
Derfor er vi tvunget til at reflektere og begrunde alle valg, vi foretager. For at fastholde en sammenhæengende biografisk fortalling må den posttraditionelle identitet konstant forhandles og legitimeres (Giddens 1991).

I det posttraditionelle er identitet blevet hårdt arbejde. Således mener den tyske kulturanalytiker Thomas Ziehe (1989a), at en af konsekvenserne af den kulturelle frisattelse, vi har oplevet siden 1950 eme, er, at vi kan og skal velge mellem flere livsbaner og tolkninger end tidligere. Vi skal præstere noget på alle livsområder. Kvinder skal fx ikke kun vare gode modre og hustruer, de skal også vare i god form, vare sexede, have en karriere osv. Forandringens stigende hastighed betyder ogsa, at vi hele tiden står overfor nye valg, valg, der ofte er komplekse, fordi vi gennem medieme har adgang til en enorm mængde informationer og perspektiver. Forbrugsvalg er et slaende eksempel oplyst og kompliceret af en hel industri af forbrugerinformation orn kvalitet, etik og produktionsforhold. Derfor opstär der et misforhold mellem hverdagens realiteter og de mange forventninger, der produceres i vores kultur bl.a. i medierne (billeder pả krop, succes mv). Resultatet af modernitetens kompleksiteter er en gennemgribende ambivalens en folelse af frihed blandet med en folelse af frustration (Ziehe 1989a).

Ziche mener, at den posttraditionelle refleksivitet har en sterlig karakter hos unge, saledes at den kommer til udtryk i en sarlig bevidsthed om at vare ung (Ziehe 1993). Denne type refleksivitet prager de unges reklamesmag. I informanternes favoritreklamer er figurerne praget af ambivalens. Dermed bekrafter de informanternes oplevelse af, at verden er kompleks og fuld af valg. Men reklamemes humoristiske perspektiv tilbyder en måde, man kan leve med denne posttraditionelle kompleksitet. Pigen i TeleDanmark-reklamen bliver offer for sin egen urimelighed, manden i Tuborg- reklamen handler mod bedre vidende og accepterer det, manden i Vores Ol-reklamen udviser himmelrâbende inkonsekvens. Men i stedet for at finde disse skxbner tragiske, san inviteres wi til at grine. Grinet wreducerer alvoren/betydningen af den manglende konsekvens i deres handlinger, dvs. den manglende konsistens i deres vardisystemer. Reklamerne nedtoner betydningen af at skabe en sammenhangende biografisk fortalling netop ved at foreslå, at det ikke er så alvorligt et problem, at "biografien « ikke hanger sammen. På den ene side kunne man mene, at de trivialiserer dette alvorlige 
identitetsmassige sporgsmål, på den anden side kunne man sige, at de tilbyder et perspektiv, der gor det lettere at leve med ambivalensen, I stedet for at prove at »lose disse ambivalenser, tilbyder reklamerne, at vi larer at leve med dem og grine af dem. I disse postrraditionelle komedier bliver refleksiviteten identitetens redningsbalte, reklame bliver terapi.

\section{Populaere hadereklamer: reklame som ungdomskultur}

Den engelske kultursociolog Mary Douglas mener, at moderne identitet er kendetegnet ved at vare negativt bestemt. Hvor det i traditionsbundne samfund er nemt at definere, hvem man er ud fra den kønslige og sociale position ( $\mathrm{f} x$ mand og bonde), sat er det dagens posttraditionelle samfund sverere at afgranse identiteten. Derfor definerer vi os istigende grad relationelt, i forhold til det, vi ikke er (Douglas 1996). Som vi sả oven for, er de unges oplevelse af, hvad der er dårlige rellamer, også en vigtig indgang til at forsta deres reklamesmag.

Fxlles for de reklamer der opnår status af hadereklamer er, at de opleves som minautentiske«. Gymnasiepigen Anja mente, at wde varste er de dér, hvor folk skal fortalle om produkterne, og man kan se, at det er sa falsk. Det er grimta. Tilsvarende sagde gymnasiepigen Maja om reklamekampagnen for Always Ultra hygiejnebind: $" \mathrm{De}$ siger 'det virker meget bedre. Det stinker langt væk, at de far penge for at sige det. Hele opsetningen virker så stiva. De unges hadereklamer er nasten altid produktorienterede reklamer eller reklamer, der kommer med utrovardige udsagn om produktet.

De reklamer, de unge finder mest grinagtige er dem, hvor en argumenterende form narrativisares, dvs. gøres til en historie. Det er reklamefilmen for bolschet Werters Egte, hvor bedstefaderen sidder med barnebarnet på knæet og tanker tilbage til dengang, han var dreng, og hans egen bedstefar gav ham Werters bolsjer. Det er også reklamefilmen, hvor to joggende piger stopper i parken og den slankeste og smukkeste fortzeller den anden, at hun holder sig smuk ved at spise Kinder malkesnitte, når hun tranger til et mellernmåltid. De unge opfatter sarlig Kinder-reklamen som et ảbenlyst utrovardigt forsog på at forene slik med et fitness-image. Anja sagde: »Det er ogsâ langt ude, at man kommer i totalt god form, hvis man spiser
Kinder malkesnitte«. Informanterne frastødes af disse utrovardige forsag pa iscenesatte en naturlig brugssituation, som skal sandsynliggøre de fiktive erfaringseksperters produktanprisninger. Fortallemassigt har disse reklamer det problem, at der or ikke er tale on udfoldede historier med on pointe, der rakker ud over produktanprisningen. De handler om produktet - og dermed tilbyder de ikke de unge en autonom oplevelse (af dem selv). I disse produktorienterede pseudonarrativer er det ikke, som i favoritreklamerne, personer, der er ifokus - det er varer.

Tyske tvureklamer er et kapitel for sig, fordi amatoragtig stemme-synkronisering fär i forvejen hảbløse reklamer for vaskemidler og hårshampoo til at virke dilettantiske. Gymnasie-drengen Thomas $H$. var fx irriteret over, at smunden farer frem og tilbagek. De unges afsky for disse reklamer handler også om, at de ikke kan identificere sig med produkterne (rengøring, bleer mv.) - som de heller ikke er målgruppe for - og det spligtunivers«, de ofte er en del af. En lige så vigtig årsag til, at netop disse reklamer lagges for had, er, at de ofte sendes efter en såkald » txppebombningsstrategi«. De vises efter en massiv sendeplan i lange perioder, med bred kanaldsekning og hoj frekvens (mange ugentlige visninger på mange kanaler).

Reklamen spiller generelt ikke den store rolle, nảr unge er sammen. Man taler sjeldent om reklamer og da oftest om de dårlige reklamer. Faktisk er det sådan, at unges whadereklamer er de reklamer, der har storst chance for at blive en aktiv del af de unges kulturer - til tider opnår de endda kultstatus. De citeres igen og igen og bliver en del afet ungdommeligt sprog, af de unges indforstanede og fortrolige mäde at definere deres sociale fallesskab pä. De unge havner sig på reklamemes åbenlyse undervurdering af sit publikum ved at parodiere dem. Samtidig kan reklamecitaterne bruges til at markere personlig integritet. $\mathbb{F x}$ kan man skabe distance til en folelsesladet situation, som när gymnasiedrengen Kristian citerer tigeren i en Kellogs-reklame og siger: »Det er great . Man kan også som gymnasicpigen Ina bruge citater, når man er ude at shoppe. Ina kunne $\mathrm{fx}_{\mathrm{x}}$ sige sprov det, prev det « til en veninde, når veninden ytrede sig positivt om noget toj og tilsvarende wjamen, det er jo hele tre ting «, hvis en veninde virkelig shopm pede stort ind. Masske bruges citaterne i denne situation til at skabe en indforståct kritisk distance til reklame-/forbrugskulturen en distance, der kan 
markere, at Ina ikke er slave af forbrugskulturen, og som kan legitimere shoppe-turens lystfyldte og legende karakter.

\section{Danske sit coms}

Der er dog også gode reklamer, der formår at blive en aktiv og levende del af de unges fellesskaber. Det galder sarlig en type reklamefilm, man kunne kalde »danske sit coms», der sæerlig er populare bland gymnasiedrengene og i ovrigt også i resten af befolkningen (Rothenborg 1998).

11997 indledte fargeselskabet Scandlines en re klamekampagne, hvor to måger beklagede sig over, at de nye frerger sejlede să hurtigt, at de ikke kunne folge med mere. Kampagnen blev så popular i sin forste sendeperiode, at den skabte seerstorm påTV2, fordi seere ringede ind for at sporge om, hvornår den naeste reklame kom, og hvor man kunne kobe dukkeme. Reklameme indledes med, at mågerne hilser på hinanden ${ }^{H} \mathrm{Hej} \mathrm{Kaj}, \mathrm{Halloj}$ Bøje«, og variationer over denne hilsen havde på interviewtidspunktet bredt sig blandt de unge. Blandt mine informanter navnte et par af gymnasiedrengene denne kampagne som en favorit og Thomas $\mathrm{H}$. fortalte, at han imiterede reklamerne for sin kareste.

Eksempler på danske sit coms fra 1990'erne er ud over Scandlines-kampagnen, Squash-reklamerne med Finn og Jacob, Fiskeindustriens reklamer med Minna og Gunnar, Sonofon-reklamerne med Timm og Gordon og kampagnen for Wasa knækbrad med de to svenske lagerarbejdere. Kampagnen for Boller fra Kohberg befinder sig i graenselandet mellem de posturaditionelle komedier og de danske sit coms.

De danske sit coms minder meget om den amerikanske sit com-genre, der også er populxr blandt teenage-drenge. Som de unges andre favoritter er disse reklamer praget af ekstrem enkelhed. Det er reklameserier med smá afsluttede historier; komiske situationer, der altid foregär i samme kulisse og med de samme karakterer hver gang. Gentagelsen er således et vigtigt element, og gentagelsen skrives også ind i dialogen, hvor pregnante one-liners bliver emblematiske udtryk for reklamernes figurer og universer: "Det er ikk så ringe endda«, »jeg vil gerne have en Skvas og $\gg$ Hva Sorensen er den af du gamle er eksempler.

Genremassigt trakker de danske sit coms også på den danske folkekomedies brug af folkekare skuespillere og enfoldige figurer, ${ }^{3}$ samt på revytra- ditionens sketches. Humoren er ofte crazy humor, og der er næsten altid tale om et umage par - »det sjove makkerparu. To skxve typer, saerlinge, som har et fortrolig og ligevardigt om end ofte ambivalent forhold til hinanden. De udgor således ikke en identitetsmassig trussel mod de unge, som reklamens idealfigurer kan gore det, men virker i deres fejlbarlighed meget menneskelige. Samtidig formår de at vare sammen uden at give køb på sig selv og deres personlighed, selv om de altid er alene sammen og således befinder sig i en intim social situation.

\section{Sproget og det sociale}

Samtalen er i centrum i de danske sit coms. Emnet er ikke så vigtigt, det vigtige er den fatiske kommunikation, dvs. dét at man snakker sammen. Enten taler man om trivielle emner eller også trivialiseres emnet $o g$ behandles på en mmeningslos « måde, så det bliver samvarets karakter frem for indholdet, der bliver betydningsfuldt. Fx sidder Kaj og Boje på hver sin fxerge i en af Scandlincs-reklameme. Hver gang fargerne passerer hinanden, hilser mågerne på hinanden $» H_{e j} \mathrm{~K}$ aj«, »Halloj Bøye«. Dette gentager sig ti gange, hvorefter pointen prasenteres: fargerne sejler hele dagen lang. De danske sitcoms tilbyder et altemativt univers til skolens $\mathrm{og}$ voksenverdenens rationalitet og formuft et ungdommeligt legerum, hvor de unge kan bemestre sproget samtidig med, at de negerer dets universelle mmeningstyrannik. ${ }^{4}$ Således kan samtalerne kredse om produktet uden at give egentlig information om det. Det primære er stemningen og den sproglige kreativitet den skore, indforståede energi i makkerparrets forhold. Og serieformatets gentagelse gor det let at leve sig ind i denne stemning. Reklameme spiller på genkendelsens glade og på barndommens rollelege, der også gennemspilles igen og igen. Reklamerne tilbyder ogsả de unge en falles genkendelig ramme at agere inden for i sociale situationer.

Det sjove makkerpar kan skabe en indforstået, legende og kreativ stemning, der minder om den kemi, der er mellem gode venner, og derfor har de danske sit coms faktisk storre chance for at nả ud i ungdomskulturerne end posttraditionelle kom medier. De sjove makkerpars samvar og deres sproglige kreativitet giver materiale til de unges samvar med vennerne: både i form af gode citater og frem for alt $\mathrm{i}$ form af inspiration til, hvordan man skaber sjove, indforstäede, venskabelige si- 
tuationer. Her kan gymnasiedrengene hente inspiration til, hvordan man indgăr i intime relationer uden at miste personlighed. De danske sit roms tilbyder $\mathrm{f} x$ de unge citatmateriale. Det handler ikke om stof til dybe filosofiske samtaler men fx om sjove one-liners, der skal reaktivere reklameoplevelsen for at skabe en god stemning og for at etablere et falles univers.

Citater fra disse sjove, citérbare reklamer kan ikke bare bruges til at skabe en god stemning, de kan også kommunikere smag og vardier, vare med til at opbygge en falles erfaringsverden, demonstrere overlegenhed over reklamerne og kreativ kompetence. De danske sit coms giver således gymnasiedrengene materiale til det sociale samvar. Disse reklamer er ligesom de posttraditionelle komedier sjove danske reklamefilm, men deres identifikatoriske forankringspunkt er ikke situationernes genkendelighed, men derimod gentagelsen og den surreelle interaktion mellem karaktererne. De iscenesatter intime sociale (tomands) situationer og giver inspiration og materiale til samvaret med andre unge. Hvor de posttraditionelle fortallinger giver materiale til konstruktionen af den personlige identitet, să giver de danske sit coms altså snarere materiale til konstruktionen af den sociale identitet.

\section{De levende billeder}

De unges foretrukne reklamemedie er reklamefimen. Alle uden undtagelse nevner uopfordret reklamefilm, når de taler om, hvilke reklamer de sidst har set, hvilke reklamer de synes er gode hhv. dårlige. Det er reklamefilm, de unge husker, og det er dem, de bedst kan lide. Som navnt var informanternes primære kvalitetskriterie genkendelighed og autenticitet, og kognitivistisk filmteori beskriver faktisk levende billeder som en udtryksform med immanent mulighed for at skabe en oplevelse af netop disse kvaliteter.

Hvor det skrevne ord skal formidle betydning udelukkende ved hjolp af symbolske tegn, har billeder yderligere en rokke muligheder. I lighed med tegningen har de levende billeder muligheden for at skabe identifikation ved hyxlp af indexikalske tegn, dvs tegn, der ligner noget, vi kender fra virkeligheden. Falles med fotografiet har de levende billeder desuden muligheden for at skabe identifikation ved hixlp af ikoniske tegn, som er tegn der peger pa billedets narhed med virkeligheden, dvs. at det er et aftryk af virkeligheden (Messaris 1997).
Endelig har de levende billeder den særegne egenskab, at de ved hjolp af den klassiske billedfortallings redigeringsprincipper (etableringsindstilling, krydsklipning, pov) kan skabe et univers, der ligger meget tat på hverdagserfaringen (Grodal 1994). Reklamefilmen har således storre mulighed for at udfolde en narvarende fortalling end fx reklamefotoet.

Meget tyder på, at det er tv, og ikke biografen, der er informanternes primare reference. De unge beskriver ofte reklamerne som $»$ den fra tv $\ll$, og de navner lige så mange hadereklamer som favoritreklamer, og hadereklamerne har ofte kun været vist $i$ tw. Dette hanger formodentlig sarmmen med tv-mediets centrale position ogsä i de 16-20 ăriges liv, selv om de faktisk er den gruppe, der, på grund af deres meget aktive og udadvendte livsstil, ser mindst tv (Fridberg 1997). Samtidig er tv-reklamer et af de få falles referencepunkter, de unge har. Som noget unikt sendes tv-reklamer mange gange og på flere forskellige kanaler, således at chancen for, at andre i omgangskredsen har set en reklame, er stor (mange af dem har også vaeret vist i biografen). TV-reklamen har således storre mulighed for at blive del af de unges sociale fallesskaber end andre reklametyper ja faktisk kan man sige, at tv-reklamen er den eneste tilbagevarende fallesnationale mediegenre.

\section{Den globale ungdom - og den nationale}

Som det er fremgået, er de unges favoritter danske. reklamer. Olreklamer for Tuborg, Vores Olog Faxe er de mest populare, men også reklamer for TeleDanmark, Tipstjenesten, Squash og Scandlines fremhaves. De unge foretrakker sjove danske filmfortallinger.

Tidens unge lever i en international kulturs virtuelle smagsfallesskaber og har på mange màder mere til falles med hinanden pă tvacrs af landegranser, end de har med landsmænd $i$ andre aldersgrupper. 1990 'ernes teenagere cr knyttet sammen af internationale medier (MTV, popmusik, film, tv-serier, computerspil og Internet) og af en forbrugskultur, der er domineret af internationale markevarer. Men den globale medie- og forbrugskulturs store betydning for ungdomskulturerne kommer ikke til udtryk i mine informanters reklamesmag, og det tyder på, at den danske kultur sta- 
dig er en endog meget stxrk identitetsskabende faktor:

Den danske sociolog Peter Gundelach har på grundlag af en stor curopxisk vardiundersøgelse sammenlignet holdninger hos danske unge mellem 18 og 25 år med andre europacere is samme aldersgruppe (Gundelach 1993:7-8). Danske unge giver udtryk for en hoj grad af selvstandighed og ansvarlighed. De vil selv tage stilling, og de afviser i hojere grad autoriteter end unge $i$ andre lande. Arsagen finder han i den danske borneopdragelse, hvor selvstzendighed betyder mere end $i$ andre europaiske lande. Den danske opdragelse lagger vegt på tolerance og ansvarsfolelse, hvor man i andre lande lagger storre vagt på lydighed, sparsommelighed og den kristne tro: $\gg$ Vi lytter ikke til autoriteter for at finde ud af, hvad der er rigtigt og forkert. I stedet bruger vi diskussion og samtale, og vi vil helst forhandle os til rette \& (Gundelach 1993: 7).

Abenbart er de posttraditionelle traxk langt mere fremherskende i Danmark end i resten af Europa og dermed også refleksiviteten. Måske hænger behovet for at reflektere den posttraditionelle identitet, som vi ser i informanternes reception af de posttraditionelle komedier, også sammen med den danske opdragelse på en anden led. Ambivam lensen overfor det »ungdommelige a afspejler mäske en sarlig modvilje mod at ssynke ned i $\mathrm{i}$ ungdomskulturen. Danske unge skal ofre meget, năr de trader ind $\mathrm{i}$ ungdomskulturen, for $\mathrm{i}$ bruddet med foraldrene må de nemlig til en vis grad give afkald på den ubetingede fortrolighed, accept og forstålse, som de făr af forældrene qua idealet om, at der er og skal vare et demokratisk, ábent og ligevardigt forhold mellem born og voksne (selv det ungdommelige opror har danske foraldre fuld forståclse for og anser som et sundt selvstandighedstegn). I ungdomskulturen skal de unge derimod legitimere deres eksistens og kampe for opmarksomhed.

\section{Reklame, vare, livsstil}

»Hvis forbrugeren kan lide en kampagne er der en overvejende sandsynlighed for, at det smitter af på produktetes siger Steen Lassøe, dircktor for Dansk Markedsforingsforbund (Rothenberg 1999). Reklamebranchen lever af forestillingen om, at der er en sammenhang mellem en reklames popularitet og salget af det annoncerede produkt og denne sammenhang skal helst kunne dokumenteres.
Men de unges praference for danske reklamer viser, at der ikke er nogen sammenhang mellem de unges reklamekultur og deres forbrugskultur. De unges makevarepraferencer påvirker overhovedet ikke deres reklamepraferencer og omvendt.

De unge navner kun produktet for at »navngive« reklamerne, de reflekterer kun sjaldent over forholdet mellem reklame og produkt. Forholdet til produktet tages kun op til overvejelse, når der er tale om utrovardige produktiscenesattelser, som vi så det med Anjas kommentar til reklamen for Kinder Mrelkesnitte. Fx er det meget almindeligt, som vi så det med Anton, at informanterne husker produktkategorien, men ikke det varemarke der reklameres for. Ofte er der endda et totalt misforhold mellem reklamesmag og markevaresmag. Rune kunne lide McDonalds reklamer og gik kun på Burger King, Thomas K. ogThomas H. kunne ikke lide Diesels reklamer, men gik i tojet. De mest populaere reklamer er da heller ikke reklamer for de markevarer, der er mest populare blandt unge. Adspurgt om deres markevarepraferencer nævnte de unge igen og igen de store internationale markevarer: Levis, Diesel, Coca Cola, Nike, Adidas, Hugo Boss og Calvin Klein. Det er da ogsă disse annoncorer, der retter deres reklamer specifikt mod teenagere. Alligevel sæiter reklamerne for disse varemarker sig ikke fast $\mathrm{i}$ de unges bevidsthed. De deciderede ungdomsreklamer er kun en del af de unges passive erindring ikke deres aktive. ${ }^{5}$ De unge taler med andre ord kun om disse reklamer, når jeg navner dem.

Disse resultater tyder på, at annoncorerne »skyder ved siden af klamexstetikkens udvikling. Markevarereklamer losrives i stigende grad fra de produkter, de skal synliggore, og fungerer i stedet på popularkulturens promisser, de bliver selvstændige kulturprodukter - underholdning. En anden årsag er, at reklamebranchen er befolket af stilorienterede bymennesker, der i vid udstrakning laver reklamer til sig sclv. Anders Hoiris, dircktor i rcklamcbureauet Egebjerg mener, at der er for meget kobenhavneri i reklamen: sStore dele af branchen har glemt, at der findes et Danmark udenfor Larsbjornsstrade og de andre smarte gader omkring Strogete (Rothenberg 1996: 6).

Branchen ville formodentlig forklare misforholdet pă folgende mảde. For det forste at brudreklamerne primart er rettet mod trendsettere, og at det derfor er ligegyldigt, om almindelige unge kan lide dem log det er endda ikke helt alminde- 
lige unge, jeg har interviewet det er nemlig unge, der bor i Kobenhavn. Ifolge reklamenbranchens logik skulle dette betyde, at deres smag er mere trendsatter-agtig, end det gxlder unge i andre dele af landet $){ }^{6}$ For det andet at malet med disse reklamer ofte er at satte gang i en mediedebat at gøre reklamerne til del af en kulturel positioneringsproces. Det vigtige er ikke, om de unge kan lide reklamerne, men at »de voksne ikke kan. Det er năr de voksne og de professionelle meningdannere lufter deres rigtige meninger om, hvor forkastelige reklamerne er, at reklamerne bliver autentiske udtryk for en ungdommelig identitet og dermed interessante for unge. Disse forklaringer efterlader dog reklamebranchen med et problem nemlig dokumentation. Kan branchen ikke dokumentere et sammenfald mellem de unges smag og de (brud)reklamer, branchen laver, sả kan den heller ikke sandsynliggore sammenhxengen mellem reklame og salg empirisk kun teoretisk.

\section{Smagfulde metoder}

De unges favoritreklamer var ubetinget de posttraditionelle komedier, og det er overraskende, når man ser det i forholdet til 1990 'ernes ungdomsreklame, der $i$ vid udstrakning benytter sig af brud-astetik. En af grundene til at mine informanter fokuserer på reklamer med mere "personlige historier" er formodentlig den personlige interviewform. Inden for sociologien er det en udbredt forestilling, at holdninger cr situationsbestemte, og det har faet nogle sociologer til at konkludere, at holdninger er arbitrare (se Dahl 1997). Jeg vil dog havde, at man fär mere ud af at anskue holdninger som lokale og kontekstuelle fanomener. Visse situationer har tendens til at producere en bestemt type holdninger, mens andre situationer producerer en anden type. Den personlige interviewform producerer intimitet og fortrolighed - her kan man uden ansigtstab og sociale hensyn tale om sig selv. Dermed skabes en ramme, hvor det bliver mere oplagt at tale om reklamer, der tematiserer det subjektive og personlige. Dette kan til en vis grad forklare, at en bestemt og for mig overraskende reklametype er så popular hos unge.

Reklamebranchens udbredte brug af fokusgrupper i tests af unges holdning til reklamer rummer nok en af forklaringerne på, at branchen har en anden forestilling om unges reklamesmag. I fokusgruppen skabes betydningerne i den sociale dynamik. Der sker en holdningspositionering, hvor opinionslederne kommer til at fore ordet og satte dagsordenen for, hvordan man taler om reklamen eller varen. Dermed bliver det den mest kompetente og derfor også ofte mest astetisk progressive holdning, der kommer til at prage betydningsdannelsen. Samtidig vil der i en »offentlig « social interaktion naturligt blive lagt vagt på at presentere og positionere den sociale identitetet, dvs. holdninger og smag. Således vil reklamer der tematiserer sadanne forhold, fx brudreklamerne, have storre sandsynlighed for at blive sat på dagsordenen i cn fokusgruppe.

Den metodiske konsekvens af mine resultater er naturligvis, at triangulering en kombination af flere forskellige metoder pr. automatik mả indgá i empiriske undersøgelser af smag. Samtidig må overvejelser over empirisk metode i storre omfang indgả som en integreret del af både undersogelsesdesign og resultater, og disse overvejelser må rumme en bevidsthed om metodens betydning, ikke blot for hrordan de unge snakker om et frenomen, men også - mere grundlaggende - om, hoad det overhovedet er for fxomomener, de snakker om.

Et element i en sådan metodisk refleksitvitet må vare en overvejelse af, om den kvalitative metode har storre forklaringsvaerdi end den kvantitative i denne type af undersegelse. Min begrundelse for at valge det kvalitative interview contra det kvantitative var, at at jeg ikke blot ville vide noget om, hvilke reklamer informanterne kunne lide, men også hvorfor. Det kvalitative interview bygger pă den antagelse, at det $\mathrm{i}$ vid udstrakning or muligt at bevidst- og sprogliggore sine erfaringer og praferencer, og at man har lyst og evne til at formidlo disse erfaringer til en ukendt person. Denne antagelse er tvivlsom. I mine interviews blev der abnet et enormt fortolkningsrum, men informanterne havde svart ved at komme ud over den umiddelbare, sanselige karakteristik af deres reklameoplevelser. ${ }^{7}$ Informanternes refleksioner begransede sig ofte til $» g o d \ll o g »$ flot $\ll$ og jeg havde på fornemmelsen, at de hurtigt kom til at fole, at de gjorde vold på sig selv, når jeg opfordrede dem til at uddybe deres oplevelser.

\section{En god historie}

Mine informanter orienterer sig mod en helt anden type reklamer end brudreklamerne. Deres reception kredser ikke om social identitet, men snarere om personlig autenticitet; den kredser ikke om kropsreprasentationer, men snarere om sin- 
dre k kvaliteter; og den er ikke stilorienteret, men snarere indlevet $\mathrm{g}$ h handingsorienteret.

Således ligger tidens fremherskende brudxstetik langt fra salmindelige « unges smag. Selv ikke năr informanterne distancerer sig fra reklamen og den etablerede kultur, lader de brudreklamerne formulere deres distance. I stedet kommer distancen til udtryk i en afsmag over for hadereklamerog overgearede »amerikanske « reklamer og en preference for de danske sit coms med deres 'fjollede' og legende stemning.

Informanternes favoritreklamer er danske reklamefilm med enkle, sjove historier, der udspiller sig i hverdagsagtige universer. Dette er noget overraskende, for det stemmer ikke overens med de dominerende forestillinger om unges reklamesmag. Som navnt forsoger de reklamer, der er målrettet mod unge, at appellere ved hjalp af brud-xestetik. Men selv om de unge foretrakker Diesels og Smirnoffs negerende brudreklamer frem for hadereklamerne og de overgearede mamerikanske « reklam mer, så er deres favoritter altså 'positive' fortallinger, fortallinger der skaber deres egne danske universer. Brud-reklamerne er stort set virkningslose over for mine informanter. Nok bruger de selv distancerende, cool strategier, når de bringer hadereklameme ind i deres samtaler, men i deres favoritrcklamer søger de genkendelige og trovardige personer og situationer.

Mine uddybende sporgsmål afslørede, at informanterne kendte brudreklamerne og synes, at mange af dem er gode. Sarlig de unge der kommer fra moderne og idealistiske kulturer, hvor foreldrene fx er akademikere, synes om reklamer der er moralsk, eksistenticlt og astetisk udfordrende. Specielt er Diesels for »succesful living a og Smirnoffs $»$ pure thrill -kampagner populare. Nogle af pigerne gemte fx Diesel-kataloger som en slags kunstboger.

Livsstilsforskningen bekrafter da også, at det er mennesker, der kommer fra moderne og idealistiske livsstilsmiljoer, der definerer, hvad der er god smag. Det er dem der sidder på samfundets kulturelle kapital og bestemmer, hvad der er smukt og progressivt ( $\mathrm{x}$ det minimalistiske danske design). De moderne idealister fungerer som trendsettere på xestetikkens omräde, og deres astetiske ideal er »det alternative (Dahl 1997: 158). Men selv unge, der kom fra disse kulturer, foretrak klassisk fortallende reklamefilm. Dette sxtter sporgsmältegn ved, on de unges reklamesmag nu ogsả cr sả overskridende og brudorienteret, som reklamebran- chen mener, den cr. Lagger man for stor vaegt pả forestillingen om, at den centrale del af identitetsarbejdet forcgår som en social positionering i forhold til andre kulturer ( $\mathrm{fx}$ den etablerede kultur)? Og overser man samtidig den del af identitetsarbejdet, der foregår som cn personlig sogen? Lagger man for stor vagt på de moderne krops-og stilorienterede trak ved ungdomskultureme? Og overser man dermed andre (more) grundlaggende track? Glemmer man i begejstringen over de unges kulturelle mangfoldighed, at ungdom også er en periode praget af ofte voldsomme biologiske og psykologiske forandringer, der kraver intens cksistentiel selvrefleksion? Og glemmer man i sin fascination af den »ungdommelige livsstil «, at unge maske ikke altid har de livserfaringer, der skal til for at opleve verden, ligesom voksne gor?

Det sidste menerThomas Ziehe: De unge ved i høj grad, 'hvordan' de er, og det gor det ikke lettere for dem. Hvad de (endnu) mătte have af oprindelighed, det mangler de (fortsat) i suverenitet. Ungdom, sådan som den optrader $i$ sin egen forestilling, den har de ingen rădighed over. A priorialene i kraft af deres lavere alder - er de ikke mere bevagelige, mere spontane, mere sanselige, mere erotiske eller mere astetiske end de voksne. Forst i det øjeblik, man selv tilegner sig det at vare ung, bliver det muligt at gestalte disse kvaliteter og igivet fald nyde dem - men så er man ikke læengere rigtig ung « (Ziehe 1989b: 134).

Informanternes smag tyder pa, at deres ambivalens over for det moderne er storre, end det almindeligvis antages. De foretrekker ikke xtetisk og eksistentielt udfordrende reklamer; de kaster sig ikke frygtlost ud i modernitetens forandring af moral, krop og astetik. I stedet foretrakker de reklamer, de kan bruge til at reflektere deres egne oplevelser med at skulle udvikle en selvstændig identitet og samtidig vare en del af en ungdomskultur. De er med andre ord snarere til "Woody Allensreklamer end bil »Pulp Fiction«-reklamer.

Interessen for krop og stil var hos alle de unge underordnet interessen for en god historie med sympatiske figurer genkendelige eller sjove. Det indlevende blik var overordnct det stilbevidste, og det på trods af at reklamen qua sine mange visninger og sin hoje produktionsvardi (beregnet i prom duktionspris pr minut er reklamen den dyreste tygenre) er den genre, der i storst grad liegger op til et stilbevidst blik. De unge vil have historier om. autentiske personer, men de orienterer sig ikke mod dannelseshistorier, der tilbyder en afklaret 
identitet. I stedet orienterer de sig mod film, der fastholder en identitetsmassig åbenhed. Posttraditionelle komedier der giver trovardige og konstruktive bud på det senmoderne livs kompleksitet.

De unge foretrak ker reklamer, der kan beskrive virkeligheden som den er. Det er dog ikke en virkeligheds-astetik som den dokumentariske realisme, man ser i tidens brudreklame, hvor udkorte, sårbare og lidende unge memnesker stirrer tomt frem for sig (Thorup 1997, Wallerstein 1999). Det er heller ikke reality-reklame, som nár almindelige mennesker hentes ind fra gaden og bruges som modeller (som i Caterpillars reklamekampagne og Magasin du Nords katalog $»$ Real life fra marts 2000). Formelt foretrakker informanterne derimod udtryksrealisme, dvs fortelleformer der mimer hverdagens oplevelscsmåde. Hvad angăr handling forerakker de en meksistentick realisme, dvs. form tallinger on centrale oplevelser i de unges liv, fortallinger der ligesom den gode kunst kan reflektere informanternes grundlaggende eksistentielle vilkår.

Resultater som disse, hvor de astetiske tendenser ligger fjernt fra den faktiske reception, satter sporgsmälstegn ved den måde, vi foretager kulturanalyse på. Her trenker jeg på den udbredte praksis, hvor man analyserer et astetisk fonomen - $\mathrm{fx}$ tidens brudreklame - og dernæst ser dette fanomen som udtryk for en generel ungdomskulturel udviklingstendens (som man ser det hos fx Jerslev 1993, Kellner 1995, Jhally 1995, Højbjerg 1996 og Wallerstein 1998). Det er $i$ vid udstræekning denne type 'omvendt bevisforelse', der har varet med til at skabe billedet af unges smag som udpreget progressiv. Denne praksis giver dog i bedste fald kun et begranset udsnit af virkeligheden, og forhåbentlig kan empiriske undersogelser som beskrevet i denne artikel vaere med til at synliggore, hvor problematisk denne praksis er.

\section{Noter}

1. Disse tendenser beskrives i Thorup 1997, Kleivan 1998 og Wallerstein 1998.

2. Filmen hedder $S m u k$, smukkere og er produceret af Wibroc, Duckert \& Partners, der har produceret alle reklamer for Gron Tuborg siden 1975.

3. Disse reklamer găr da ogsă ofte under betegnelsen wden danske folkekomedie-reklame (Rothenborg 1998).

4. Reklamerne virker som vitsen ved at åbne op mod det udgransede og tabuerede (her: legenidet barnlige). Legen kan accepteres, fordi den kommer til udtryk isproget (dvs i en voksen diskursform). Så kan det kaldes mintelektuel legu eller kreativitet.

5. Om forholdet mellem relevans, forstalse og erinm dring se Findahlog Höjer (1989).

6. Mediabureauet Carat udtaler i forbindelse med en undersogelse af kobenhavnske unges Lesevaner, at wtendensen blandt de unge ofte starter i Kobenhavn og siden breder sig til resten af landet (Politiken 2000).

7. Detre gjaldt ogra gymnasieeleverne, der generelt var meget åbne og glade for at tale om deres smag og holdninger. Eleverne fra teknisk skole var udpremget minaktive og havde storre tendens til at se mig som interviewer og autorite (laerer). De bemestrede ikke sproget sa godt som gymnasiedeverne og havde ikke den samme evne dil - og behov for - at reflektere over deres reklamesmag og -oplevelser.

\section{Litteratur}

BBDO (1994) Future Kuth Kobenhavn: BBDO.

Bourdicu, Pierre (1984) Distinction. A Sorial Critique of the Judgement of Taste London: Routledge. Opr. 1979.

Dahl, Henrik (1997) Hus div nabo at en bil Kobenhavn: Akademisk Forlag.

Douglas, Mary (1996) Though Stples: Critical Eswas on Good Taste London: Routledge.

Drotner, Kirsten (1995) wdviklinger og udfordringer Sockal Forskning, Januar: 61-65.

Drotner, Kirsten (1999) Wnge, wedwer, modenite: polinger $i$ et foranderligt landshab Kobenhavn: Borgen.

Ewen, Stuat (1988) All Consuming Imager The Politics of Sitle in Contomporary Culure New York: Basic Books.

Findahl, Olle \& Birgitta Höjer (1989) Begriphghetsandys: en forshningygenomgang och on thampning pa whetsindslag rad io och iv Land: Studenterlitteratur.

Fridberg, Torben mA. (1997) Monstre i mangfoldigheden: de 15-18-anges medibug i Daman Kobenhavn: Borgen.

Giddens, Anthony (199) Modernity and Sef-identity Cambridge: Polity Press.

Grodal, Torben K. (1994) Cognition, Emotion and Vistal Fic thon Kobenhavn: Kobenhavns Universitet.

Goth \& Raffols reklamebureau (1996) Zap Atad Markedsundersogelse til intern brug i reklamebureauet Goth \& Raffel, Kobenhavn.

Gundelach, Peter (1993) wan skal kumestyre sigw, Wu tol $3: 7,70$.

Hojbjerg, Lemard (1996) Fortulleteri 2: MushudeogreKamefim Kobenhavn: Akademisk Forlag

Jerslev, Anne (1993) w Wye tendenser i filmkulturenk, pp. 139-59 in Fublum og Futwhum Alborg: Amanda.

Jhally, Sut (1995) "Image Based Culture Ads and Popu" lar Culture«, pp, 77-87 in Gail Dines \&ean M. Hu mez Gendew, Race and Class in Medh Thousand Oaks: Sage.

Kaspersen, Lars Bo (1996): Anthony Giddens ;, pp. 400-1l in Lars Bo Kaspersen og Heine Andersen (red) Kasisk og modeme samfindsteori Kobenhavn: Hans Reitzel. 
Kellner, Douglas (1995) *Television, Advertising, and the Construction of Postmodern Identitiesk, pp. 23162 in Media Culwre: Cultural Studies, Identity and Politics between the Modern and the Postmodern Media Culture London: Routledge.

Kleivan, Birna Marianne (1998) »De salger på dod og ulykke«, Samuirke maj: $28-33$.

Larsen, Ole Schultz (1999) Fom aldre* thdulingenfrafodsed til pubertet Arhus: Systime.

McCann-Erickson (1994) Saktewo og store bluser: om unge i govne Markedsundersogelse til intern brug i rekla* mebureauet McCann-Erickson, Kobenhavn.

Messaris, Paul (1997) Visual Peruation: The Use of Trages in Adverting London: Sage.

Nava, Mica og Orson Nava (1990) wDiscriminating on Duped? Young People As Consumers of Advertising Artu, Magazine of Cultural Studies 1: 15-21. Genoptrykt in Mica Nava (1992) Changing Cultures: Feminism, Louth and Consumerim Newbury Park: Sage.

ODonohue, Stephanie (1997) "Leaky Boundaries: Intertextuality and Young Adult Experiences of Advertising «, pp. 257-275 in Mica Nava mfl, (red) Buy This Book London: Routledge.

Politiken (2000) Sektion Modiak, 9.4 .

Rothenborg, Michael (1996) >Når reklamer bliver for smarten, Poliken 30.10.

Rothenborg, Michael (1998) »Dansk or dejlgst «, Politiken 15.9
Rothenborg, Michael (1999) »Folkets fisk ", Poliken 1.11.

Stomboj, Christel (1994) s Konsumption som kommunikationa, pp. 132-50 in Fredrik Miegel \& Thomas Johansson (red) Mardrommar och Onshedwmmar Stockholm: Symposion.

Thorup, John (1997) *State of the Ads " pp. 91-120 in K ir sten Drotner og Karen K. Povlsen (red) Tankestreger: me medier, andre unge Kabenhavn: Borgen.

Thomp, John (1999) w Hor er den ironiske genera tion? \&, Medikulur: 40-52.

Tufte, Birgite (1994) w Er tw-reklame kon? «pp. 102-110 in Brit Fougner og Mona Larsen-Asp (red) Norden: koinners paradis Kobenhavn: Nordisk Ministerrâd.

Wallerstein, Katharine (1998) Thimness and Other Refusals in Contemporary Fashion Advertisementse, Fashion Theory 2, 2: 129-150.

Willis, Paul (1990) Common Culture Buckingham: Open University Press.

Ziche Thomas (1989a) \$Fremad mod halvtredsernes, pp. 11-24 in Ambivalenser og mang foldghed Kobenhavn: Politisk Revy.

Ziehe Thomas (1989b) w Ungdommelighed og kropsbileder«, pp. 129-37 in Rultwanalyser: Ungdom, whildning, modemile' Stockholm/Stehag: Symposion Bokforlag.

Ziche, Thomas (1994) wrom Living Standard to Life Stylea, Loung: Nordic Joumal of houth Reseach 2, 2: 2-16. 